tion and Classification of Scientific Knowledge, held at Trinity College, Cambridge, on October 25, 1947.

"The use of documentary reproduction for auxiliary publication, and its eminent suitability as an aid to science and learning in general, were the subject of two articles in Nature $(157,29,38 ; 1946)$, where a new type of service was forecast to 'keep men of science currently informed of all the literature published on their respective subjects'. It was there, also, that the setting up of central agencies was suggested and interchange of services and close co-operation with bibliographical centres and scientific institutions was advocated. A memorandum to this effect was also submitted to Unesco (through the offices of its predecessor, the Conference of Allied Ministers of Education, 1945). In a paper read to the Royal Society Empire Scientific Conference, 1946 (Report, vol. 1, pp. 717-721), and another put before the Co-operation Committee of the Library Associa. tion in the same year, the setting up of a Central Office of Documentary Reproduction was recommended to act as a co-ordinating centre for Great Britain and the British Commonwealth and Empire; while a renewed appeal for the co-ordination of policy in Documentary Reproduction on a world scale was made to the Sixteenth Conference of the International Federation of Documentation in Paris, November 1946 (F.I.D. Communicationes, 13, Fasc. 4, 60; 1946). For the furtherance of these ideas, Mr. Watson Davis' letter has provided valuable evidence which should bring closer to realization some of the services for which the plans have been prepared in former years."

\section{British Commonwealth of Nations Scientific Liaison Offices}

THE British Commonwealth of Nations Scientific Liaison Offices (London) have been opened on the third floor of Africa House, Kingsway, W.C.2. This is one of the measures to facilitate co-operation in the civil aspects of science within the Commonwealth decided on by the British Commonwealth Scientific Official Conference held in London in 1946. For a number of years several of the Commonwealth countries have maintained scientific liaison offices in London, and these, together with the ones now being established, will have their headquarters in Africa House. Each of these offices will continue to operate as in the past, retaining complete independence of action; but the convenience of occupying adjacent premises will facilitate co-operation between them on matters of common interest. For ease of reference to the group of independent offices as a whole, the title given above has been chosen, with the abbrevia. tion B.C.S.O. (London) for common use. The offices taking part in the scheme are those of Australia, Canada, Central African Council, India, New Zealand, South Africa and the United Kingdom. Pakistan and the Commonwealth Agricultural Bureaux will be represented, and the Overseas Liaison Division of the U.K. Department of Scientific and Industrial Research will work in Africa House. In Washington the scientific liaison offices of the Commonwealth countries are associated under a similar scheme.

\section{British Seismological Observatories}

THE Stonyhurst College Observatory has now ceased to record earthquakes, as has also the Royal Observatory at Edinburgh. Mr. E. W. Pollard has moved from the Isle of Wight to Dorking, Surrey, and hopes to set up his seismograph at his new home. He has presented a seismograph with mass $40 \mathrm{lb}$. to the County Secondary Grammar School at Newport, Isle of Wight, where the instrument has been set up and is being standardized. It is hoped to install good time-keeping apparatus shortly.

\section{International Seismological Summary}

SnNCE the British Association meeting in September 1947, the United Nations Educational, Scientific and Cultural Organisation has given a substantial grantin-aid to the International Union of Geodesy and Geophysics for the International Seismological Summary (see Nature, April 17, p. 616). The staff of the I.S.S., consisting of Mr. J. S. Hughes and two assistants, have been at work at Kew for more than a year now, and the full issue for the year 1936 has been produced and partly distributed. In addition, much work has been done on the Summary for 1937, portions of this being in the hands of the printers. We are informed by Dr. Wang Ging-Hsi, of the Natural Sciences Section of Unesco, that the Organ. isation will assist similarly with another grant in the present year.

\section{Natural History Journals}

ONE by one som? of the journals whose light flickered and went out in 1939 are being revived. The latest is the Scottish Naturalist which now enters on its fifth stage under the joint editorship of Prof. V. C. Wynne-Edwards and Dr. J. W. Campbell. The first volume of the new series is mainly devoted to birds of Scotland. That country has also produced a new journal, Scottish Zoo and Wild Life; this has been inaugurated by the Zoological Society of Scot. land for the bənefit of its fellow's and all who are interested in animal life. Cordial wishes for their success are extended to both these journals while naturalists everywhere will also wish to congratulate the North-Western Naturalist on reaching its twentyfirst anniversary under the able editorship of $\mathrm{Mr}$. A. A. Dalliman.

\section{National Advisory Council for Education in Industry and Commerce}

THE following have been elected to serve on the Standing Committee of the National Advisory Council for Education in Industry and Commerce: Lieut.-General Sir Ronald Weeks (ehairman), Sir Samuel Gurney-Dixon (vice-chairman), Sir Graham Savage, Mr. E. L. Russell, Mr. A. Ballard, Dr. Percy Dunsheath, Prof. F. H. Garner, Prof. R. G. Batson, Sir Robert Wood, Dr. T. J. Drakeley, Dr. H. Schofield, Mr. J. Wilson, Dr. J. E. Myers, Sir Charles Tennyson, Sir Arthur Smout, Mr. G. S. Heaven, Sir Arthur Fleming, Mr. B. J. Ewing, Mr. G. H. Lowthian, Mr. W. T. Mainwaring, Mr. M. F. Titterington, M.P., Mr. E. G. Gooch, M.P., Dr. F. C. Toy, the Hon. Josiah Wedgwood, Captain A. M. Holbein. Sir Samuel Gurney-Dixon was also elected vice-chairman of the Council.

\section{Institution of Mining and Metallurgy: Awards}

THE Gold Medal of the Institution of Mining and Metallurgy, the highest distinction which the Council of the Institution has power to grant, has been awarded to Mr. G. Carleton Jones, resident director in South Africa of New Consolidated Gold Fields, Ltd., in recognition of his distinguished services to the gold mining industry of South Africa, and in particular to the development of the West Rand. Honorary membership of the Institution has been 